\title{
RANCANG BANGUN PERANGKAT LUNAK DATABASE DENT AND BUCKLE CHART PADA PESAWAT BOEING 737-800
}

\author{
Fahmi Nugraha Santosa*, Mufti Arifin, Endah Yuniarti \\ Prodi Teknik Penerbangan, Fakultas Teknologi Kedirgantaraan, \\ Universitas Dirgantara Marsekal Suryadarma \\ Komplek Bandara Halim Perdanakusuma, Jakarta 13610, Indonesia \\ Corresponding Author: fahminugrahas26@gmail.com
}

\begin{abstract}
Abstrak - Pemeliharaan pada pesawat terbang harus tercatat rapi dan lengkap menurut CASR Part 145, dimana salah satu pencatatan pemeliharaan yaitu catatan pada setiap komponen yang mengalami kerusakan dan perbaikan. Semua dicatat berdasarkan lokasi komponen, tanggal ditemukan dan dokumen yang berkaitan dengan kerusakan dan perbaikan tersebut. Contoh catatan pemeliharaan adalah dent and buckle chart (DBC). Dent and buckle chart yaitu catatan kerusakan dan perbaikan yang telah dilakukan pada struktur pesawat terbang. Fungsi dari DBC ini yaitu untuk memudahkan dalam pencarian riwayat kerusakan dan perbaikan pada pesawat terbang. Penelitian ini berupa rancang bangun perangkat lunak database DBC, tujuannya memudahkan pencatatan DBC, dan penggunaannya dapat diakses di semua device seperti PC (Personal Computer) dan smartphone. Perangkat lunak ini berupa website yang diberi nama "Sysdnb" dan telah dibuat untuk mencatat kerusakan dan perbaikan yang ada pada pesawat tipe B737-800. Metode yang digunakan dalam penelitian ini adalah pertama mengumpulkan data catatan perbaikan dan kerusakan B737-800, kemudian membuat Sysdnb dan input data catatan ke database. Setelah selesai membuat Sysdnb dan data sudah ter-input adalah trial Sysdnb. Hasil trial menunjukkan pencatatan kerusakan dan perbaikan pada pesawat B737-800. Sysdnb ini berhasil dibuat untuk memudahkan personil lapangan dalam melakukan pencarian riwayat kerusakan dan perbaikan pada pesawat B737-800 dan keterbatasan dari sysdnb ini yaitu tetap harus membuka dokumen SRM secara manual.
\end{abstract}

Kata kunci : Rancang bangun sysdnb, database, dent and buckle (DBC), pesawat boeing 737-800

Abstract - Maintenance on an aircraft must be neatly and completely recorded according to CASR Part 145 , where one of the maintenance records is a record of each component that is damaged and repaired. All are recorded based on the location of the component, date found and documents relating to the damage and repair. Examples of maintenance records are the dent and buckle chart (DBC). Dent and buckle chart is a record of damage and repairs that have been made to aircraft structures. The function of this $D B C$ is to facilitate the search for a history of damage and repairs to aircraft. This research is in the form of $D B C$ database software design, its purpose is to make it easier to record DBC, and its use can be accessed on all devices such as PCs (Personal Computers) and smartphones. This software is in the form of a website called "Sysdnb" and has been made to record the damage and repairs that exist on the type B737-800 aircraft. The method used in this study is to first collect the B737-800 repair and damage log data, then create a Sysdnb and input the log data to the database. After completing Sysdnb and the data has been input is a trial Sysdnb. The trial results show the recording of damage and repairs on the B737-800 aircraft. This system was successfully created to facilitate field personnel in searching for a history of damage and repairs on the B737-800 aircraft and the limitation of this system is that it still has to open SRM documents manually.

Keywords: Sysdnb design, database, dent and buckle chart (DBC), boeing 737-800 


\section{PENDAHULUAN}

Pesawat terbang merupakan sarana transportasi udara yang banyak diminati oleh masyarakat saat ini dan juga perlu pemeliharaan yang baik, dimana pesawat terbang juga memiliki batas kemampuan pada setiap komponen strukturnya dan juga akan mengalami perubahan pada struktur maupun performa pesawat itu sendiri. Oleh karena itu untuk menjaga struktur dengan baik, pesawat diperlukan pencatatan pemeliharaan tersendiri yaitu mengumpulkan semua data perbaikan pesawat agar semua pelaksanaan pemeliharaan terjadwal dengan baik.

Proses mencatat kerusakan dan perbaikan itu masih kurang efektif karena line maintenance ada yang malas melakukan pencatatan kerusakan dan perbaikan dan malas menyimpan catatannya. Pencarian data kerusakan dan perbaikan harus mudah diketahui untuk meminimalisir kesalahan pada saat penjadwalan pemeliharaan selanjutnya dan untuk menghindari denda pada saat penjualan ataupun pengembalian pesawat terbang. Pencarian data kerusakan dan perbaikan pada pesawat juga harus lengkap dan jelas. Pencatatan pemeliharaan pesawat terbang dinamakan dent and buckle chart (DBC). Line maintenance melakukan visual check / perbaikan setelah itu melakukan pencatatan pada dent and buckle chart yang berakibat lembaran dokumen DBC akan bertumpuk dan sulit melakukan pencarian riwayat DBC-nya kembali.

Pembuatan perangkat lunak database dent and buckle chart (Sysdnb) yang berfungsi mempermudah pencatatan kerusakan dan perbaikan yang ada pada pesawat sangat diperlukan. Perangkat lunak ini harus dapat mencatat semua kerusakan dan perbaikan komponen pesawat dari mulai waktu terjadinya kerusakan, letak kerusakannya, dokumen yang berkaitan dengan kerusakan tersebut, dan kapan waktu perbaikannya. Catatan DBC yang dibuat harus mudah dilihat maka dibuat DBC berbentuk tabel pada website yang bisa menampilkan catatan secara lengkap termasuk gambar yang berkaitan, sehingga mudah untuk melakukan pencatatan DBC karena dapat diakses secara online. Hal ini akan mempermudah analisis bagi engineering dan inspeksi serta repair bagi teknisi pesawat terbang.

Objek penelitian ini adalah pesawat B737-800, karena pesawat B737-800 merupakan pesawat yang cukup banyak digunakan di Indonesia pada berbagai rute penerbangan.

\section{METODE PENELITIAN}

\subsection{Pemeliharaan (Maintenance)}

Pemeliharaan atau maintenance industri termasuk tugas-tugas yang diperlukan untuk mengembalikan atau mempertahankan sistem pesawat, komponen struktur dan struktur dalam kondisi laik terbang (Airworthy). Maintenance didefinisikan sebagai "Maintenance the performance of tasks required to ansure the continuining airworthiness of an aircraft, including any one or combination of overhaul, inspection, replacement, defect rectification, and the embodiment of a modification or repair" atau dapat juga didefinisikan kinerja yang diperlukan atau dibutuhkan untuk menjamin keberlangsungan kelayakan terbang dari sebuah pesawat, termasuk diantaranya satu atau gabungan dari maintenance, terdiri dari overhaul, inspeksi, pengujian komponen struktur, perbaikan cacat, dan modifikasi atau perbaikan.

\subsection{Inspect and Repair}

Dari struktur pesawat terbang yang ada, dimana seluruh struktur pasti ada beberapa yang mengalami kerusakan dan perbaikan. Struktur pesawat terbang setiap beberapa flight hour harus melakukan pemeliharaan dimana jika suatu pesawat pernah mengalami kegagalan/insiden kerusakan (damage) biasanya proses inspeksi atau pemeliharaan menggunakan metode NDT (Non Destructive Test) yang meliputi $^{[2]}$ :
a. Visual Inspection
b. Liquid Penetrant Test
c. Magnetic Particle Inspection 


\section{d. Ultrasonic inspection \\ e. Eddy Current Inspection}

Dari inspeksi yang disebutkan tersebut merupakan inspeksi yang sering digunakan untuk mendeteksi kegagalan/kerusakan yang pernah dialami struktur pesawat terbang yaitu, seperti:

- Buckling: Suatu jenis kegagalan pada umumnya ditandai oleh defleksi lateral yang merupakan hasil dari penekanan pada bagian struktural.

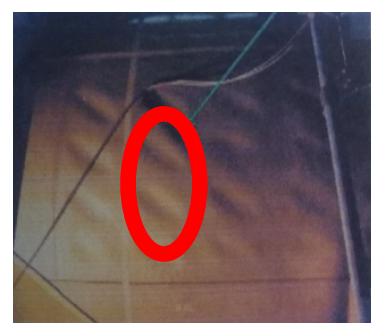

(a)

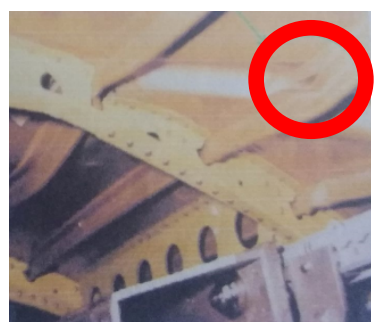

(b)
Gambar 2.1 (a) Local skin buckling between stiffeners - outer view ${ }^{[3]}$, (b) Skin/stiffener debonding - inner view ${ }^{[3]}$

- Corrosion: Kerusakan yang merupakan hasil dari tindakan elektro-kimia yang kompleks, dan memberikan perubahan luas penampang.

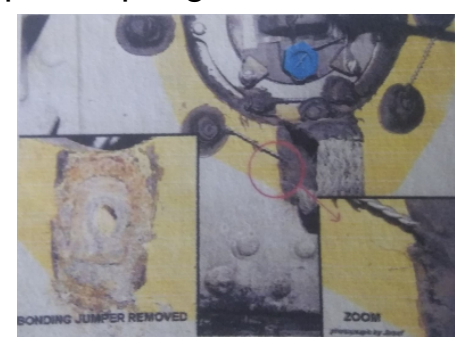

Gambar 2.2 Corrosion (Korosi) pada skin pesawat ${ }^{[3]}$

- Crack: sebuah ketidaksinambungan dalam material yang menyebabkan luas penampangnya berubah kawasan. Kerusakan ini biasanya memiliki garis yang tidak teratur dan sering terjadi. Dampak tersebut biasanya terjadi karena hasil dari kelelahan dalam material.

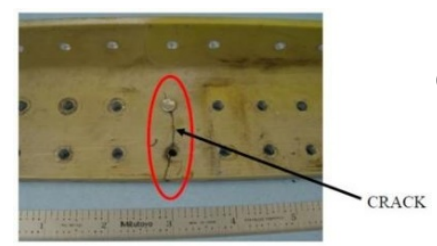

Gambar 2.3 Crack

(Retak) pada permukaan plat ${ }^{[3]}$
- Delamination: suatu jenis pemisahan ikatan (disbond) yang terjadi antara lapisan yang berdekatan antara material.

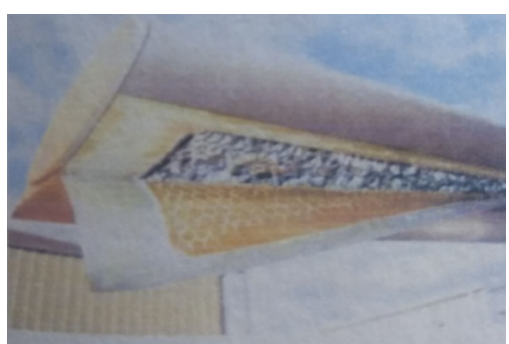

Gambar 2.4 Delamination pada skin pesawat ${ }^{[3]}$

- Dent: sebuah bagian yang rusak yang didorong dari garis luar normalnya dengan tidak ada perubahan dalam luas penampang material. Tepian bagian yang rusak yang halus. Kerusakan ini biasanya disebabkan oleh hantaman/ pukulan dari sebuah objek dengan mulus berkontur.

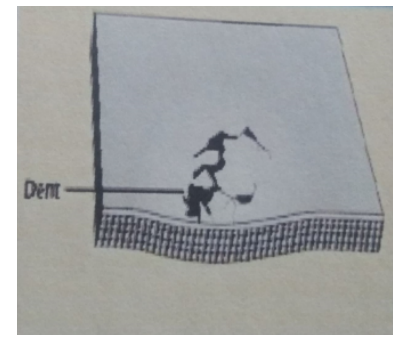

Gambar 2.5 Dent pada skin pesawat ${ }^{[3]}$

- Fatigue: kelelahan struktur akibat pembebanan yang berulang-ulang. Biasanya terjadi karena seringnya mendapat gaya-gaya mekanik.

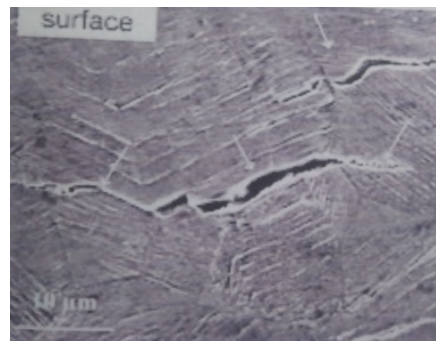

Gambar 2.6 Fatigue pada skin pesawat ${ }^{[3]}$

- Lightning Strike: kegagalan material yang disebabkan oleh sambaran petir. Kerusakan dapat dilihat sebagai perubahan warna, pits, lubang dan atau material yang meleleh. 


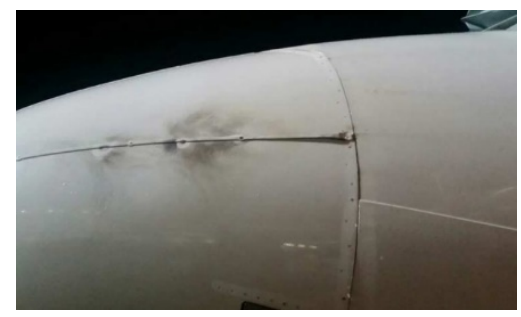

Gambar 2.7 Lightning strike pada nose fuselage ${ }^{[3]}$

Segala jenis repair pesawat memerlukan kepatuhan terhadap standar dan prosedur tertentu. Peraturan mensyaratkan bahwa pesawat udara harus dipertahankan dalam kondisi layak terbang. Jadi, ketika sebuah pesawat diperbaiki, tujuan utamanya adalah mengembalikan kondisi (aman) yang layak terbang. Adapun beberapa jenis perbaikan yaitu $^{[4]}$ :

- Doubler: plat yang dipasang di bagian permukaan luar skin pesawat, plat ini di pasang tumpang tindih dengan skin kemudian di kencangkan dengan rivet, doubler biasanya di gunakan pada daerah yang tidak terlalu mengutamakan aerodynamic smoothness, ketika melakukan pemasangan terhadap crack atau lubang kecil menggunakan doubler, kerusakan harus dihaluskan dan bersihkan terlebih dahulu, pada pengerjaan perbaikan crack, perlu di buat lubang kecil terlebih dahulu di setiap ujung crack sebelum pemasangan plat, lubang tersebut dapat mengurangi tekanan pada titik tersebut dan mencegah crack melebar.
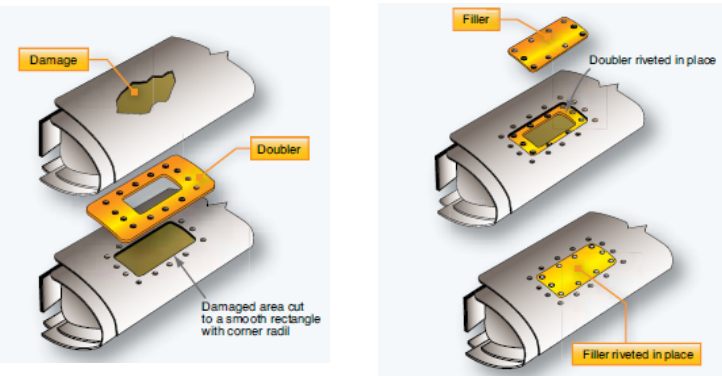

Gambar 2.8 Proses doubler ${ }^{[4]}$

- Stop Drilling: metode menghentikan pelebaran dari crack pada logam dengan mengebor lubang kecil di ujung retakan. Crack pada logam yang bergetar akan terus melebar karena tekanan terkonsentrasi pada ujungnya di area yang sangat kecil. Jika dilakukan stop drilling pada ujung retakan maka konsentrasi pada ujung retakan akan menyebar di sekitar keliling lubang, dan dibutuhkan banyak kekuatan untuk melebarnya crack.

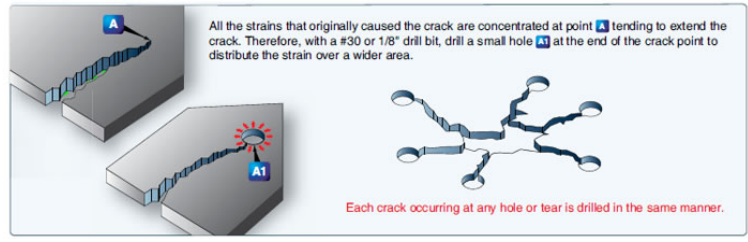

Gambar 2.9 Stop drilling of cracks $^{[4]}$

\subsection{Record Maintenance}

Menurut CASR 121 Subpart V 121.701 tentang Log Pemeliharaan Pesawat dijelaskan bahwa :

a. Setiap orang yang mengambil tindakan dalam kasus kerusakan atau perbaikan yang dilaporkan atau diamati pada badan pesawat, mesin, baling-baling, atau alat yang sangat penting untuk keselamatan penerbangan harus membuat, atau telah membuat, catatan tindakan tersebut di log perawatan pesawat.

b. Setiap pemegang sertifikat harus memiliki prosedur yang disetujui untuk menyimpan salinan memadai dari catatan yang diperlukan dalam ayat (a) bagian ini di pesawat di tempat yang mudah diakses oleh setiap kru penerbangan anggota dan harus meletakkan prosedur itu dalam manual pemegang sertifikat. ${ }^{[6]}$

\subsection{Pencatatan Dent and Buckle Chart}

Dent and buckle chart merupakan catatan kerusakan dan perbaikan yang telah dilakukan pada struktur pesawat terbang dan memungkinkan untuk mengetahui keberadaan dan lokasi kerusakan struktur. Setiap kali ada kerusakan struktur yang tidak melibatkan keselamatan penerbangan ditemukan di dalam pesawat, personil maintenance harus mencatat semua informasi terkait seperti objek, dokumen, lokasi, kategori dan tanggal ditemukannya kerusakan tersebut. 


\subsection{Structural Repair Manual (SRM) B737-800}

Structural Repair Manual (SRM) ini memberikan data umum dan instruksi khusus untuk perbaikan struktur pesawat Boeing 737-800 dan 737-800 BBJ. Manual ini memberikan data pesawat umum, prosedur umum, dan bahan-bahan perbaikan. SRM ini juga mencakup materials identification, allowable damage, dan data perbaikan untuk struktur pesawat. SRM ini dibuat sebagaimana ditentukan dalam Air Transport Association Specification 100 Spesifikasi untuk Data Teknis Produsen. Data dalam SRM ini yang memiliki peran penting pada struktur pesawat yang mana datanya telah disetujui oleh Federal Aviation Administration (FAA) ${ }^{[6]}$.

Kegunaan dari SRM adalah untuk mengetahui deskripsi dari struktur pesawat, prosedur inspeksi, struktur identifikasi, dan penentuan toleransi kerusakan pada bagian tertentu pada struktur pesawat. Structural repair manual merupakan dokumen yang "non-customized", sehingga hanya ada satu dokumen untuk tipe pesawat yang sama. ${ }^{[7]}$

\subsection{Rancang Bangun Perangkat Lunak}

\subsubsection{Hyper Text Markup Language}

Hyper Text Markup Language adalah sistem untuk menambah dokumen dengan label yang menandakan bagaimana teks di dokumen harus disajikan dan bagaimana dokumen dihubungkan bersama-sama. Hyper Text Markup Language mempunyai 2 macam ekstensi untuk kita dapat membangun dokumen HTML. Ekstensi tersebut di antaranya .htm dan .html. Ekstensi berformat .htm awalnya hanyalah untuk mengakomodasi penggunaan html dalam operasi DOS. Saat ini HTML telah mencapai versi 5, dimana beberapa fitur unggulan telah disuntikkan ke dalam program tersebut, misalnya audio, video, dan lain-lain. ${ }^{[8]}$

\subsubsection{Hypertext Preprocessor}

Hypertext Preprocessor merupakan suatu bahasa pemrograman yang difungsikan untuk membangun suatu website dinamis dan PHP menyatu dengan kode HTML, maksudnya adalah beda kondisi, HTML digunakan sebagai pembangun atau pondasi dari kerangka layout web, sedangkan PHP difungsikan sebagai prosesnya, sehingga dengan adanya PHP tersebut, sebuah web akan sangat mudah untuk di maintenance. ${ }^{\left[{ }^{[9]}\right.}$

\subsubsection{Cascading Style Sheet (CSS)}

Cascading Style Sheet merupakan suatu bahasa pemrograman web yang bertujuan untuk membuat web kita menjadi lebih menarik dan terstruktur, dalam CSS kita bisa merubah warna tabel, besar font, atau tata letak menu terkendali dari CSS sehingga semua jendela web yang berkaitan dengan perubahan tersebut secara otomatis dapat berubah, dengan CSS kita tidak perlu membuat style pada setiap file PHP, karena cukup dengan satu file CSS kita telah bisa mengendalikan semua style yang kita inginkan pada setiap file PHP yang akan ditampilkan nanti pada web browser. ${ }^{[9]}$

\subsubsection{My Structured Query Language (MySQL)}

My Structured Query Language bukan termasuk bahasa pemrograman, MySQL merupakan salah satu database populer dan mendunia, intinya MySQL bekerja menggunakan Structured Query Language. Itu dapat diartikan bahwa MySQL merupakan standar penggunaan database di dunia untuk pengolahan data. My Structured Query Language merupakan database yang mampu berjalan di semua sistem operasi, powerful. Selain itu sangat mudah sekali dipelajari, dan sepertinya hosting server juga banyak sekali mengadopsi MySQL sebagai standar database. ${ }^{[9]}$

\subsubsection{Website}

Website atau situs juga dapat diartikan sebagai kumpulan halaman yang menampilkan informasi data teks, data gambar diam atau gerak, data animasi, suara, video dan atau gabungan dari semuanya, baik yang bersifat statis maupun dinamis yang membentuk satu rangkaian bangunan yang saling terkait dimana 
masing-masing dihubungkan dengan jaringan-jaringan halaman (hyperlink). ${ }^{[9]}$

\section{HASIL DAN PEMBAHASAN}

\subsection{Pencatatan Dent and Buckle Chart Menggunakan Lembar DBC}

Pencatatan dent and buckle chart (DBC) di lapangan sebelumnya yaitu menggunakan lembar DBC dimana tahapannya sebagai berikut :

1. Line maintenance melakukan visual check pada pesawat.

2. Setelah itu, jika ditemukan kerusakan struktur pada pesawat, personil lapangan melakukan pengecekan pada kerusakan tersebut, di-identifikasi jenis kerusakannya, di-cek pada Structure Manual Repair (SRM), sehingga mendapatkan cara penanganannya. Jika harus dilakukan perbaikan maka perbaikan dilakukan oleh line maintenance itu sendiri atau line maintenance yang ter-certified untuk melakukan perbaikan kerusakan tersebut.

3. Pada setiap pesawat terdapat dokumen DBC-nya yang disebut temporary DBC (dent and buckle chart sementara) yaitu dokumen yang berisi jenis kerusakannya, dan sudah di-cek di SRM, cara penanganannya, dan telah dilakukan perbaikan. Line maintenance harus mencatat pada dokumen tersebut seperti tanggal ditemukan / diperbaikinya, jenis kerusakannya, panjang / lebarnya berapa contoh kerusakan dent dengan panjang 3", perbaikan dilakukan oleh siapa yang melakukan perbaikan, jenis metode yang digunakan dan dokumen SRM apa.

4. Langkah selanjutnya, line maintenance melaporkan dokumen temporary $D B C$ pesawat kepada engineering kemudian Engineering akan memindahkan data temporary $D B C$ ke $D B C$ yang fix, dimana termuat pencatatan $D B C$ yang lebih lengkap pada PC.

5. Langkah terakhir, dokumen DBC fix akan disimpan dan diberikan pada line maintenance sebagai pengganti dokumen temporary $D B C$ pada pesawat.

\subsection{Data Dent and Buckle Chart}

Data DBC merupakan data yang kerusakan dan perbaikan pada pesawat terbang yang diperlukan untuk mencatat dan mengetahui secara cepat bagaimana rekam jejak di suatu komponen pesawat terbang. Berikut adalah data sebelum dipindahkan ke dalam perangkat lunak seperti pada Tabel 3.1

Tabel 3.1 Kondisi catatan DBC sebelum dipindahkan ke Sysdnb

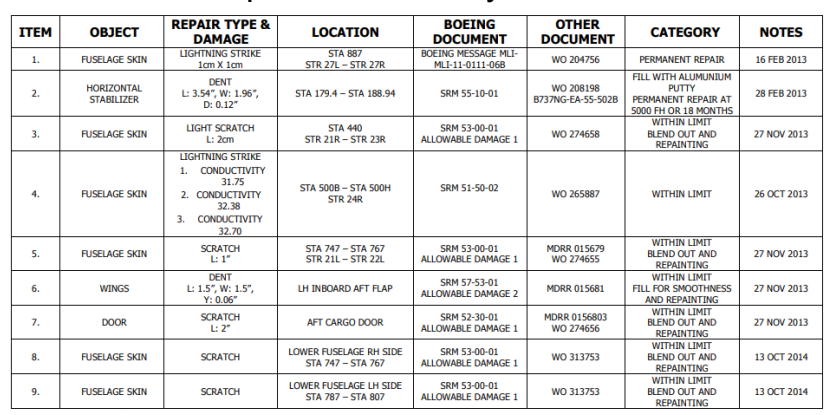

Data pada Tabel 3.1 merupakan catatan DBC yang harus dicatat secara manual oleh engineer. Keterbatasan dalam mencatat DBC dimana pencatatan hanya dapat dilakukan pada PC engineer.

\subsection{Perancangan Website}

Dalam perancangan website terdapat tahapan yang harus dilakukan dalam perancangannya, yang tersaji pada Gambar 3.1 .

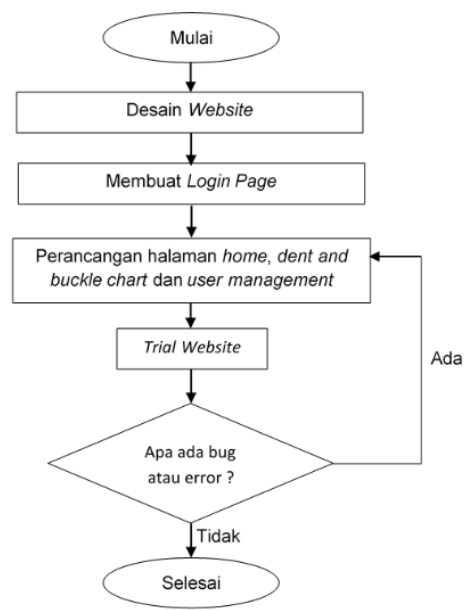

Gambar 3.1 Diagram alir perancangan website 
1. Mulai: Proses untuk memulai suatu sistem pada perancangan website yang akan dibuat.

2. Desain Website: Proses merancang bagaimana desain dari website nantinya.

3. Membuat Login Page: Halaman awal yang dibuat untuk akses isi dari website ini. Dari mulai desain dan sistemnya.

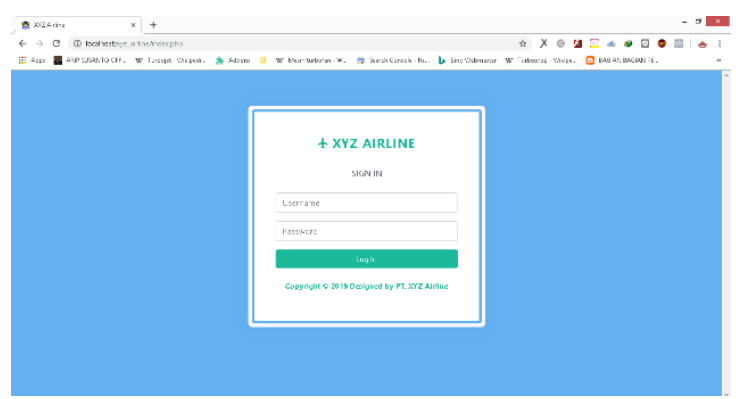

Gambar 3.2 Login page

4. Membuat Halaman Home, Dent and Buckle Chart dan User Management

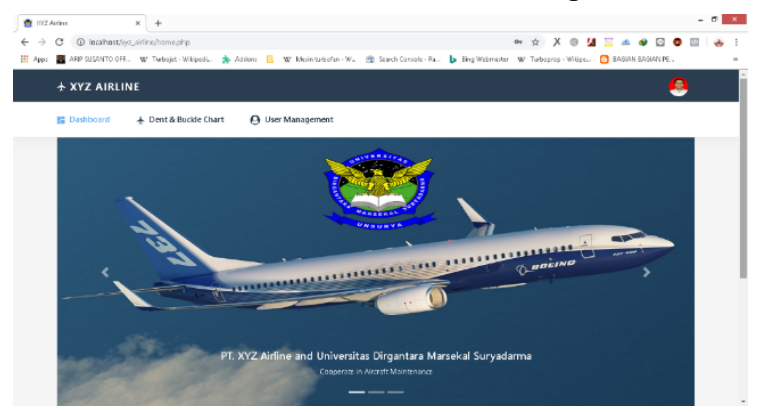

Gambar 3.3 Home

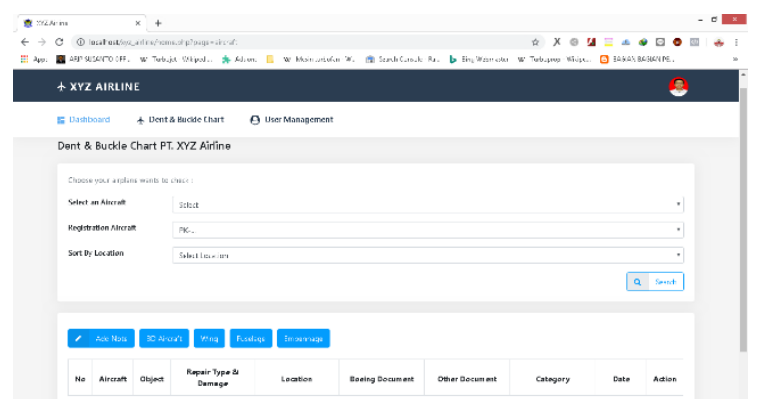

Gambar 3.4 Dent and buckle chart

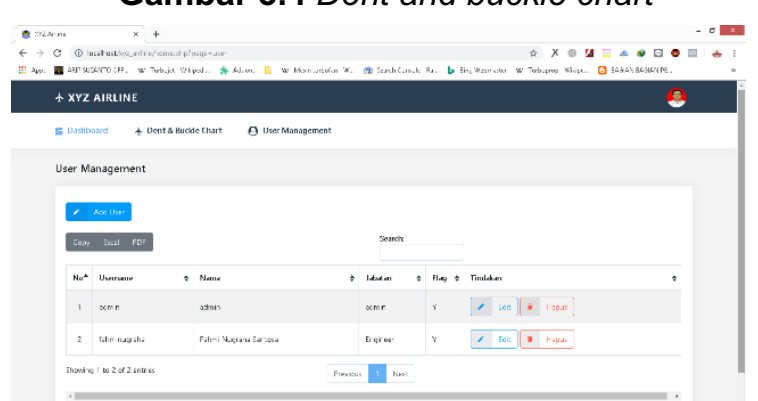

Gambar 3.5 Management user
5. Trial Website: Proses percobaan website untuk menilai bagaimana jalannya website apakah masih ada bug atau error pada website ini. Jika ada error kembali pada perancangan website.

6. Selesai: Akhir dari proses perancangan website.

\subsubsection{Perancangan Database}

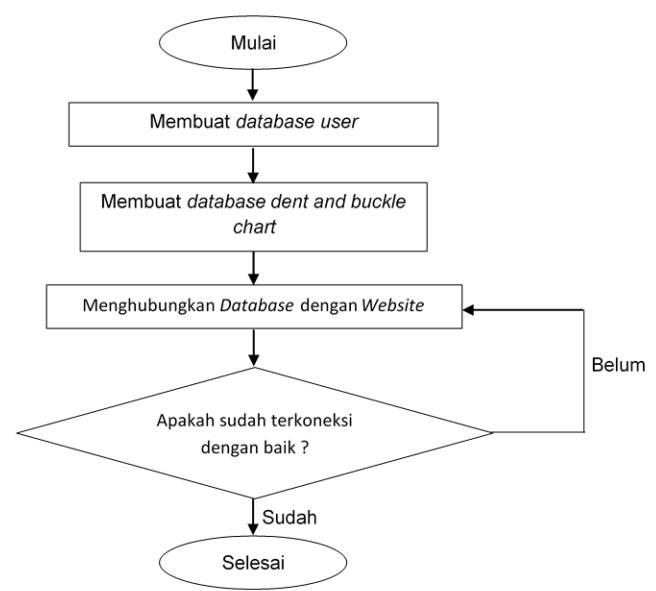

Gambar 3.6 Diagram alir perancangan database

Penjelasan dari diagram alir perancangan database adalah sebagai berikut :

1. Mulai: Proses untuk memulai suatu sistem pada perancangan database yang akan dibuat.

2. Membuat Database User: Database user dibuat untuk menghubungkan dari login page ke isi dari website, selain itu untuk keamanan isi dari website karena tidak dapat diakses semua orang tapi hanya dapat diakses oleh yang mempunyai username dan password. Berikut tampilan database user yang telah dibuat sesuai Gambar 3.7 di bawah ini.

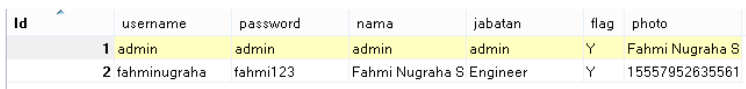

\section{Gambar 3.7 Database user}

3. Membuat Database Dent and Buckle Chart: Database dent and buckle chart dimana fungsinya untuk mencatat semua catatan dan menampilkan catatan yang ada pada database dengan mudah serta dapat merubah atau menghapusnya dengan mudah. Berikut tampilan dari 
database dent and buckle chart yang telah dibuat sesuai Gambar 3.8.

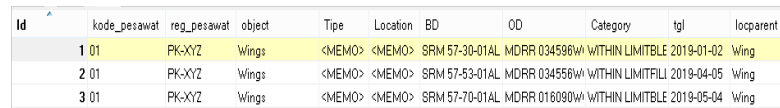

Gambar 3.8 Database dent and buckle chart

4. Menghubungkan Database dengan Website: Menghubungkan semua database dengan website dengan membuat coding.

5. Apakah sudah terkoneksi dengan baik? Suatu proses percobaan bagaimana database sudah terkoneksi baik dengan website. Jika sudah terkoneksi dengan baik, database sudah berhasil dibuat. Jika belum kembali ke langkah 4 yaitu menghubungkan database dengan website.

6. Selesai: akhir dari proses perancangan database.

\subsection{Contoh Kasus}

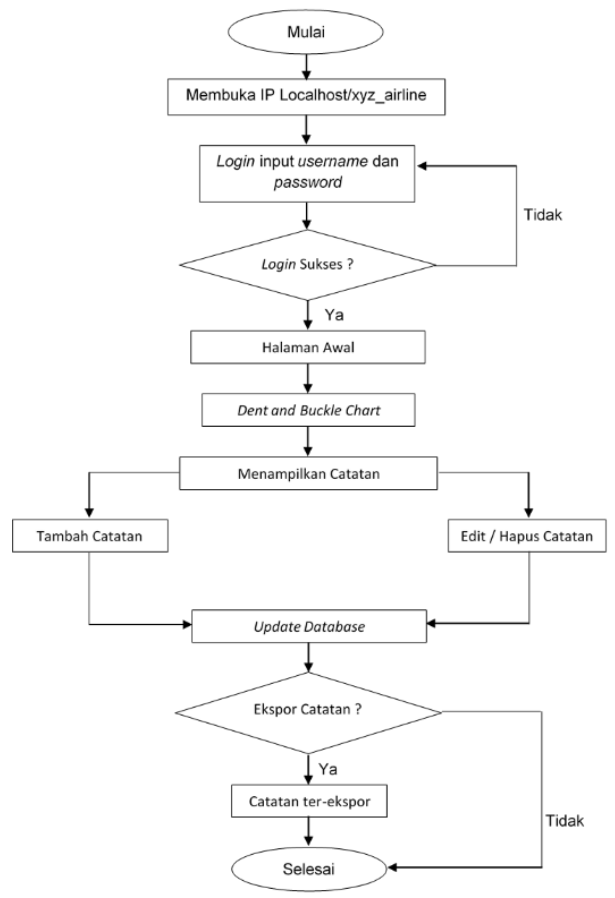

Gambar 3.9 Diagram alir contoh kasus

\subsubsection{Menambahkan Catatan Dent and Buckle Chart}

Berikut penjelasan dari diagram alir tambah catatan Sysdnb ini:
1. Mulai: proses untuk memulai suatu sistem pada penggunaan Sysdnb.

2. Membuka IP Localhost/xyz_airline: Membuka Sysdnb pada browser (Komputer/Laptop/Smartphone).

3. Login Masukkan Username dan Password: untuk mengakses isi dari website tersebut harus melewati proses login atau verifikasi user seperti pada Gambar 3.2.

4. Login Sukses?: proses ini melihat apakah username dan password yang dimasukkan sudah benar, jika iya maka proses login berlanjut ke langkah selanjutnya, jika belum maka masih tetap di halaman login.

5. Halaman Awal: setelah login berhasil maka Sysdnb akan menampilkan halaman awal seperti pada Gambar 3.3.

6. Dent and Buckle Chart: pada langkah ini dari halaman awal klik dent and buckle chart.

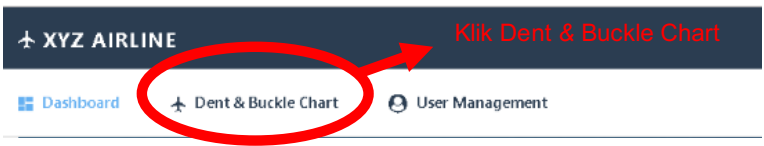

Gambar 3.10 Klik dent and buckle chart

7. Menampilkan Catatan: Pada langkah selanjutnya untuk melihat isi dari dent and buckle chart pada Sysdnb ini pilih pesawat yang ingin dilihat catatannya, pilih juga registrasi pesawat dan jika ingin lebih spesifik lagi pilih bagian lokasi pesawat seperti pada Gambar 3.11. Pada contoh kasus ini lokasi yang dipilih adalah Wing.

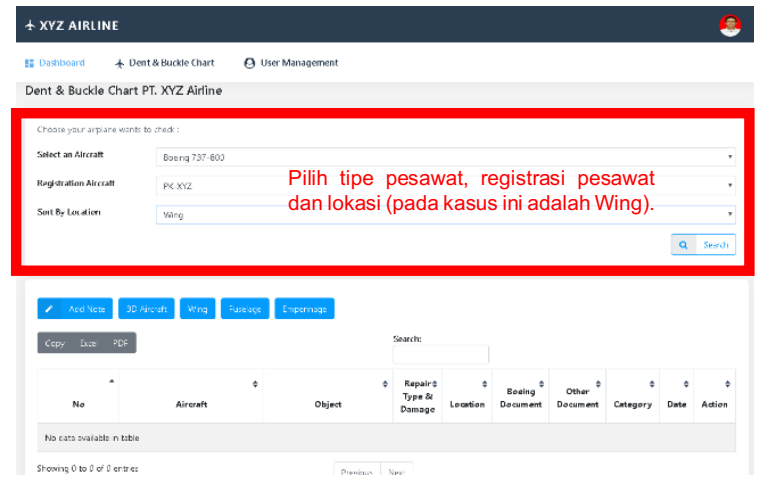

Gambar 3.11 Pilih opsi yang ada

Setelah selesai pilih opsi lalu klik "Search" dan data yang akan ditampilkan seperti pada 
Gambar 3.12, dan data berhasil dilihat hanya dengan waktu 0,0029 detik.

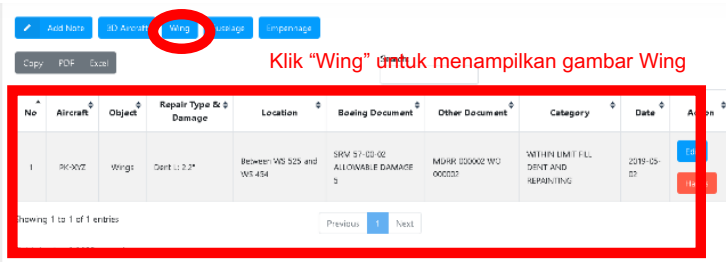

Gambar 3.12 Data catatan dent and buckle chart

Setelah klik tombol "Wing" maka gambar wing akan ditampilkan seperti pada Gambar 3.13 .

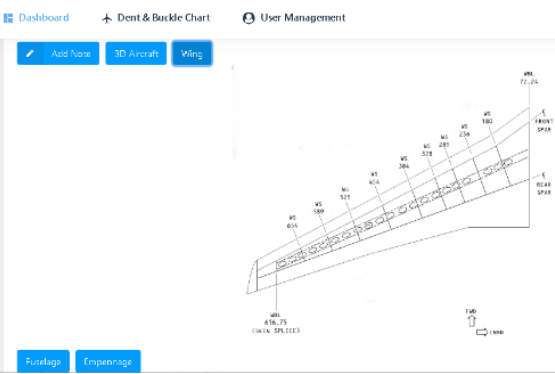

Gambar 3.13 Tampilan gambar wing station

8. Tambah Catatan: Pada contoh kasus ini data sebagai tambahan catatannya adalah

- Aircraft : PK-XYZ

- Object : Wings

- Repair Type \& Damage : LIGHTNING STRIKE D:0.002inch

- Location Detail : Winglet L/H Wing

- Location : Wing

- Boeing Document : SRM 57-30-01 ALLOWABLE DAMAGE 2

- Other Document : MDRR 000001, WO 000001

- Category : WITHIN LIMIT BLEND OUT, FILL DENT AND REPAINTING.

- Date : 05/16/2019 (MM/DD/YYYY).

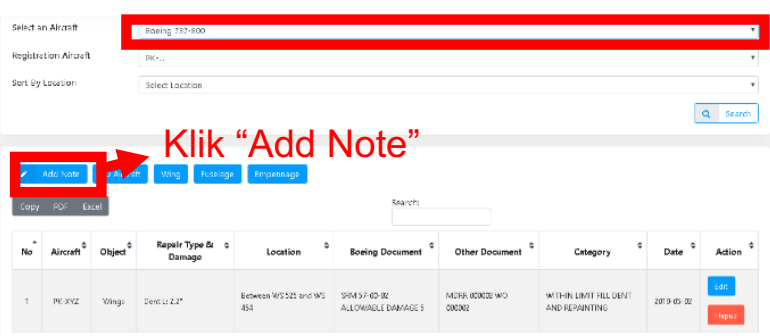

Gambar 3.14 Menambahkan catatan

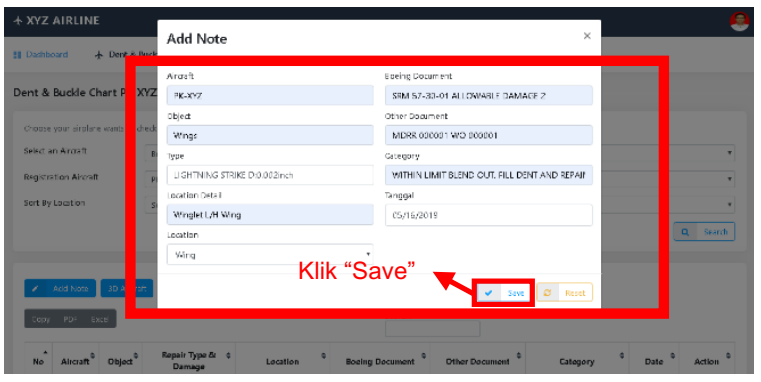

Gambar 3.15 Tampilan menambahkan catatan

Catatan ini di dapat setelah personil lapangan melakukan identifikasi dari komponen yang terjadi kerusakan dan melihat manual dalam contoh kasus ini terjadi kerusakan pada Winglet $\mathrm{L} / \mathrm{H}$ Wing karena lightning strike. Setelah itu personil lapangan mencari manual dokumen SRM yang berkaitan dengan komponen yang terjadi kerusakan, karena yang terjadi kerusakan pada winglet maka dokumen SRM yang digunakan SRM 57-30-01 Winglet Skin. Untuk keterangan allowable damage 2 didapatkan karena komponen yang terjadi kerusakan sesuai dengan SRM 57-30-01 Winglet Skin Page 101.

9. Update Database: Setelah klik save maka catatan yang baru disimpan akan langsung terupdate secara otomatis ke database dan catatan yang ditampilkan setelah menambahkan catatan adalah seperti pada gambar 3.16 dan data berhasil ditambah hanya dengan waktu 0,0041 detik.

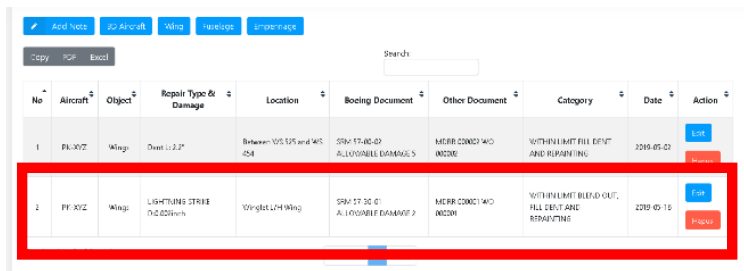

Gambar 3.16 Hasil dari menambahkan catatan

10. Ekspor Catatan: Pada contoh kasus ini ekspor catatan yang dilakukan yaitu adalah ekspor data ke PDF, tetapi jika tidak ingin meng-ekspor catatan maka hanya melihat data yang ditampilkan dan selesai. 


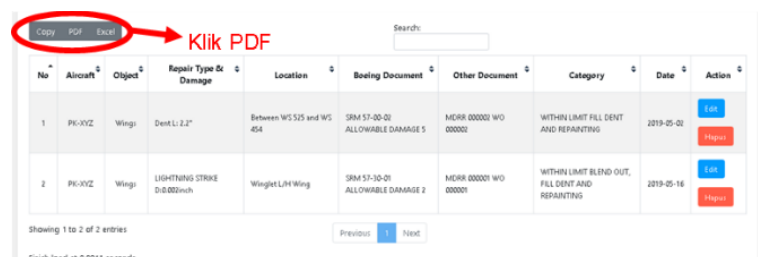

Gambar 3.17 Ekspor data ke PDF

11. Catatan Ter-ekspor: Setelah itu data akan otomatis didownload, kemudian mengecek hasil download file pada layar komputer Gambar 3.18 lalu hasil ekspor PDF yang dihasilkan adalah seperti pada Gambar 3.19.

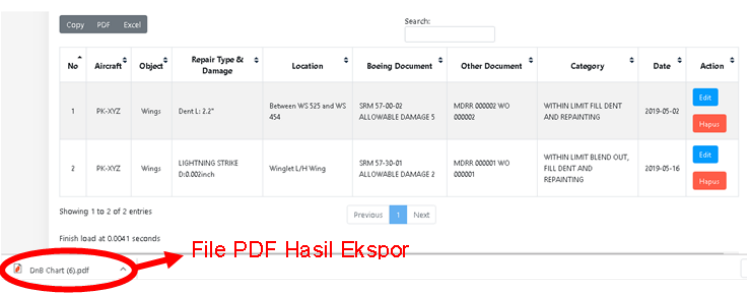

Gambar 3.18 Hasil download PDF

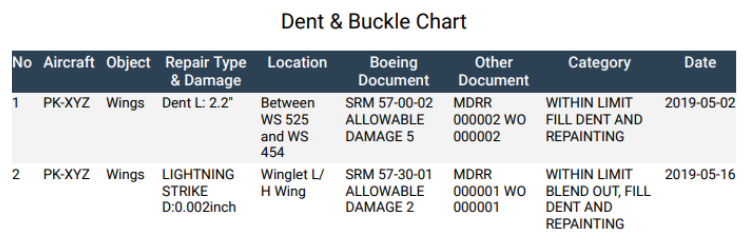

Gambar 3.19 Hasil ekspor PDF

12. Selesai: Akhir dari proses menampilkan data dan ekspor catatan.

\subsubsection{Edit / Hapus Catatan}

Langkah-langkah dalam menambahkan catatan pada contoh kasus ini adalah sebagai berikut :

1. Untuk langkah 1-7 sama dengan seperti Sub-Bab 3.4.1 sebelumnya.

2. Edit / Hapus Catatan: pada contoh kasus ini adalah merubah catatan yang baru saja ditambahkan adalah perubahan pada repair damage \& type dimana perubahan catatannya adalah D : 0.002" menjadi $0.005 "$.

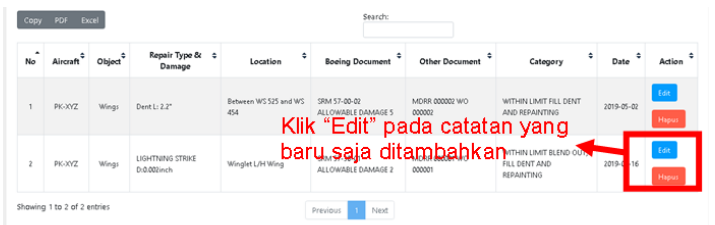

Gambar 3.20 Klik edit

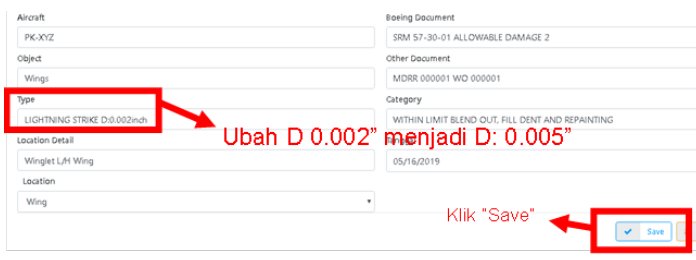

Gambar 3.21 Edit catatan

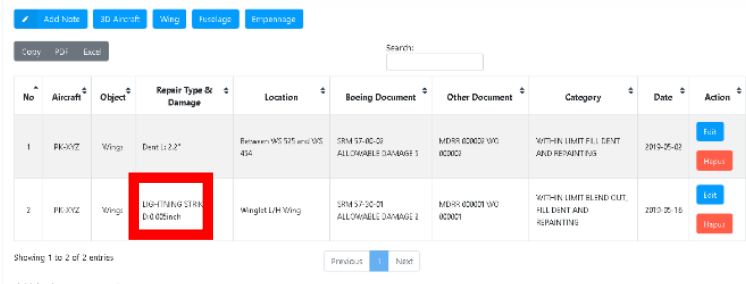

Gambar 3.22 Hasil edit catatan

Catatan berhasil diubah dan ditampilkan selama 0,0126 detik. Jika ingin melakukan perubahan catatan yang lain hanya menyesuaikan pada proses edit catatan pada Gambar 3.22. Untuk proses menghapus catatan yang ada hanya cukup klik "Hapus" pada catatan yang ingin dihapus.

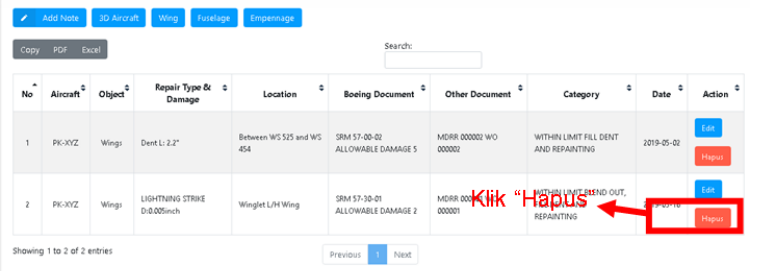

Gambar 3.23 Hapus catatan

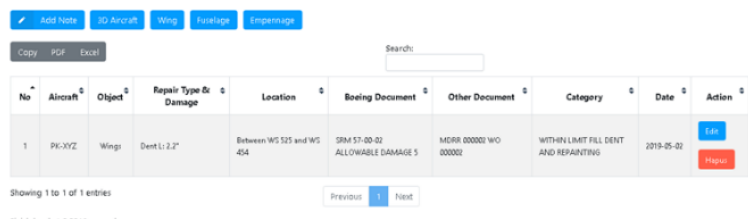

Gambar 3.24 Setelah catatan dihapus

Dari hasil simulasi hapus catatan di atas, catatan dapat terhapus dalam waktu 0,0046 detik.

3. Ekspor Catatan: sama seperti langkah 8 pada Sub-Bab 3.4.1 hanya untuk hasil ekspor datanya seperti pada Gambar 3.25 .

Dent \& Buckle Chart

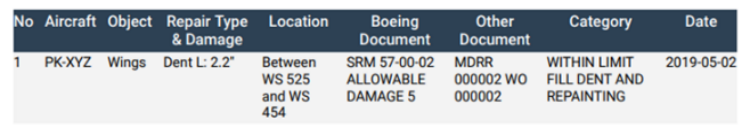

Gambar 3.25 Hasil ekspor catatan 
4. Selesai: Akhir dari proses edit/hapus catatan.

\subsection{Keuntungan dan Keterbatasan}

Berikut adalah keuntungan dengan adanya perangkat lunak DBC yaitu:

1. Mempermudah line maintenance dalam melakukan tracking kerusakan dan perbaikan pada pesawat B737-800 tanpa harus menghubungi engineering.

2. Mempersingkat waktu dalam melakukan pencatatan dent and buckle chart.

Berikut adalah keterbatasan perangkat lunak Sysdnb :

1. Tetap harus membuka SRM secara manual dalam melakukan identifikasi kerusakan dan perbaikan karena pekerjaan line maintenance yang diakui otoritas ketika line maintenance melihat dokumen SRM secara manual.

2. Dibutuhkan koneksi internet untuk membuka website ini.

\section{PENUTUP}

\subsection{Kesimpulan}

Setelah dibuatnya perangkat lunak database dent and buckle chart (Sysdnb) dan mengetahui simulasi dari penggunaan Sysdnb ini, maka dapat disimpulkan sebagai berikut :

1. Sysdnb ini dapat digunakan untuk mencatat semua catatan dent and buckle chart dan memudahkan untuk melihat catatan, edit catatan, hapus catatan dan ekspor catatan sebagai file pdf untuk dijadikan hardcopy, keterbatasan pada Sysdnb ini yaitu tetap harus melihat dokumen SRM secara manual dan membutuhkan koneksi internet.

2. Hasil simulasi dari Sysdnb ini berupa tampilan catatan dent and buckle chart yang lengkap karena terdapat juga gambar dari lokasi catatan tersebut. Waktu yang dibutuhkan untuk mengambil data dari database ke website untuk menampilkan catatan 0,0029 detik, untuk memperbarui (update) data saat menambahkan catatan 0,0041 detik, edit catatan 0,0126 detik dan hapus catatan 0,0046 detik.

\subsection{Saran}

Diharapkan Sysdnb ini dapat dikembangkan lagi pada jenis pesawat yang berbeda tipenya serta penambahan fungsi pada Sysdnb ini jadi tidak hanya diperuntukkan untuk dent and buckle chart saja.

\section{DAFTAR PUSTAKA}

1. Hutagaol, Desmond. 2013. Pengantar Penerbangan Perspektif Profesional, Jakarta : Penerbit Erlangga.

2. FAA., 2013. AC 25-29 Development of a Nondestructive Inspection Program/Organization.

3. FAA., 2018. Aviation Maintenance Technician Handbook-Airframe Volume 1.

4. FAA,. 2018. Aviation Maintenance Technician Handbook-Airframe Volume 2.

5 . ,. 2000. Repairing Sheet Metal. [Internet]. Tersedia di https://www.eaa.org/en/eaa/aircraftbuilding/building-your-aircraft/whileyoure-building/buildingarticles/metal/repairing-sheet-metal, diakses pada tanggal 22 Maret 2019.

6. CASR 121 Subpart V., 2017. Records and Reports.

7. SRM B737-800., 2018. 737-800 Structural Repair Manual The Boeing Company.

8. Agus, Mulyanto. 2009. Sistem Informasi Konsep dan Aplikasi. Yogyakarta : Pustaka Pelajar.

9. Aditama, Roki. 2012. Akademik Kampus Berbasis Web dengan PHP. Yogyakarta : Lokomedia.

10. ,. 2018. Structural Damage and Repair Report B737-800. Berkas Pdf. 24 Maret 2014.

11. .2013. Aircraft and Characteristics For Airport Planning Boeing 737. 